\title{
Off-Campus Services of the University of Michigan Library
}

Miss Flanders is chief extension librarian, University of Michigan Library.

$\mathrm{U}$

NIVERSITY LIBRARIES, especially in taxsupported institutions, have traditionally supported an obligation to a larger population than the student body. Sometimes this obligation is carried out in services to alumni and former students; sometimes in extensive bibliographic, publishing and book-lending services to the entire state. Some offcampus library service is administered by the extension service through a special bureau using a special pamphlet or book collection separate from the university collection; in other institutions the service may be given by the university library using the regular staff and collection. Some service is free; for some there is a fixed fee; other agencies ask for contributions; still others expect assistance by return postage. Off-campus service is supported in part by fees in some institutions, wholly by the extension service in others, and is completely on the university library budget in still others.

The Library Extension Service of the University of Michigan combines several of these characteristics. The following comments on the development, present activities and future needs of the service may give suggestions to other university libraries interested in initiating or expanding off-campus services.

The report was prepared for the Michigan Council of State College Presidents as part of its survey of the field and extension services of the nine tax- supported institutions making up the Council. It covers the history of the service, the extent of the service to the state at the present time, makes comments on the effectiveness of the service and gives an estimate of the opportunities for future expansion.

\section{History}

In a letter dated April 6, 1916, addressed to University President Hutchins, W. W. Bishop, university librarian, stated:

The University Library, the Municipal Research Bureau, the University Extension Service, and various other departments of the University are continually in receipt of requests for information and for books from the high schools of the state and from other organizations. These requests are largely, but by no means wholly, in connection with debates. The number of these requests and the work involved in answering them have reached the point where it seems imperative that some form of organization should be provided to handle them in an efficient and proper fashion. In fact, the absence of such an organization has already led to many instances of duplication of effort, several professors or departments of the University having received requests for material on the same subject from the same place, and sending letters and pamphlets in answer.

It appears that there is no department of the State Government meeting this need. We have been in consultation with a representative of the State Library who informs us that the State Library has no special department for answering requests of this sort. It would appear that the University Library is the proper agency to undertake this work. 
We, therefore, respectfully recommend to the Regents, through you:

First, that an appropriation of $\$ 300$ be made to cover the purchase of material, (books, pamphlets and magazines), to be used in meeting such requests from high schools and other bodies. A smaller appropriation would suffice after the first year.

Second, that provision be made in the budget of the General Library for an assistant to have charge of the work of answering requests of this nature. A salary of $\$ 1,000$ is the minimum likely to secure a properly equipped assistant. It would be possible to utilize part of the time of this assistant in the Library.

Because of this need, demonstrated by requests from Michigan residents, the Regents of the University of Michigan "authorized the expenditure of a sum not to exceed $\$ 1,000$ for these purposes during the year 1916-1917" at the June, 1916 meeting.

Since that time continuous demands have been received from parent-teacher groups, farm groups, women's clubs, civic organizations and students, teachers and administrators in Michigan schools for reading lists, pamphlets, children's books, study outlines and plays. Some estimate of the demands made on the resources of the Library Extension Service is indicated by the following summary of statistics taken from the annual report of 1935-36: For the period 19161921 , a total of 7,348 packages or units of service; for the period 1926-1931, 43,947 ; and for the period 1931-1936, a total of 53,738 packages.

During the last five years, 13,696 packages containing 129,628 pieces of material were sent to borrowers. In these years the volume of requests has declined slightly, indicating a gratifying increase in local library service, especially improvement in school libraries.

By 1923, Librarian Bishop reported at an American Library Association meeting that, although the Michigan State Library at Lansing was prepared to carry on "an increasingly large circulation and traveling library service" to the state, there was still demand for the pamphlets and clippings that the Library Extension Service offered to areas in Michigan without good local library facilities.

In 1929, a special grant to the Service from the Children's Fund of Michigan allowed expansion to the state of a children's book service that had demonstrated its worth on a small scale in previous years. In recent years the playlending service has expanded greatly and the United Nations Service is now ten years old. The school consulting service, established in 1948, and library service to off-campus university students, assigned to this unit in 1949, have added to the responsibilities of the department and to its services to the state.

\section{EXTENT OF SERvices}

\section{Package Service}

One of the most extensive library services to the residents of Michigan takes the form of packages of pamphlet material dealing with current educational, economic and social problems. These packages are lent for one month. Students, teachers, librarians and administrators of elementary and secondary schools, club women and alumni of the university request assistance in obtaining research material for study projects. During the last year 1,500 requests were received. It required over 2,400 packages containing 23,000 items to fill these requests.

\section{Play Service}

Through the courtesy of drama publishers a collection of over 2,000 plays is available on loan for ten-day periods. Schools, libraries, clubs and community theatre groups find this service very helpful and make extended use of the collection. One hundred forty-three packages, usually containing at least ten plays each, were sent out last year. Pamphlet 
materials on play production, make-up and costuming were also used extensively.

\section{United Nations Material}

Every state has a Volunteer Education Center for the distribution of general information about the United Nations. The Library Extension Service is the center for Michigan. The United $\mathrm{Na}$ tions Department of Public Information sends current material to the Library Extension Service regularly for loan to Michigan residents. In addition, material is collected through educational agencies and magazines to supplement the material issued by UN headquarters. Club women, schools, libraries and churches borrowed 31 packages on this topic last year. Each year assistance is given to three or four school groups working on model UN assemblies. Large groups of adults are reached through displays of United Nations publications at educational conferences and exhibits sponsored by university units.

Individuals interested in a more detailed study of the structure and work of the United Nations are referred to one of the graduate reading rooms of the University library, which is a depository for official UN documents.

\section{Speech Activities}

For many years the Michigan High School Forensic Association has encouraged speech activities in Michigan high schools. The Library Extension Service has cooperated by lending supplementary pamphlet material to the member schools. A bibliography of pertinent material on the annual debate topic is compiled and distributed on request to member schools and to individuals. Free materials on the current debate topic are collected each year in quantity and distributed to members. After the members of the Forensic Association have been served, packages of material are lent to other schools interested in con- ducting debate and discussion programs. One hundred forty-three schools were enrolled in the debate program last year and received the bibliography and package material automatically. Twentythree additional schools requested material on the topic.

For the second semester forensic activities catalogs showing sources of speech materials suitable for oratorical work are distributed to member schools. Two hundred forty-one schools were enrolled in the second semester program last year. For original orations the department files are a rich source of up-to-date publications, much appreciated and used regularly by school librarians to supplement their local collections.

\section{Ghildren's Book Service}

From 1929 to 1954, the Library Extension Service was able to lend children's books to areas in the state without adequate local library facilities through a special $\$ 2,500$ annual grant from the Children's Fund of Michigan. The books were lent to rural schools or small village schools and formed a bright spot in the lives of children who otherwise would have no access to the fun of recreational reading. Since April, 1954, the purchase of children's books has been continued on the university library budget as a service to Michigan children. The aim is to reach children beyond the limits of organized libraries, either school or public.

During the last year 83 sets of children's books were used for exhibits; 517 sets, averaging 28 books to a set, were circulated to schools. Circulation statistics are not requested from borrowers, but if only four children read each book contained in each of the 517 sets, some 57,904 circulations would be involved. This is only a small beginning in reaching the 257,000 children in Michigan believed to be without access to local library service.

The children's books are used in many 
additional ways which bring to the attention of adults the outstanding publications that children should have as part of their growing years. They are used for exhibits at the Summer Education Conference, the Parent Education Institute, the Annual Conference of the Michigan Congress of Parents and Teachers, for special exhibits in many schools during Book Week, and for special library meetings. Twice a year the Library Extension Service compiles a list of titles of current, outstanding children's books which is distributed at conferences and by mail, on request. About 1,500 lists were used last year as book selection aids by librarians, teachers and parents. Books wanted for radio work and for limited periods for off-campus teaching use are borrowed regularly by the Broadcasting Service staff and teachers in the Extension Division of the University.

\section{Library Extension Services}

Supporting University Activities

1. School Library Consulting Service. For several years one member of the University Library Extension staff has devoted an increasing amount of time during the school year to school visiting, for the purpose of advising administrators and librarians on current practices in school library service. Visits are of two kinds: (1) those requested by the school administrator for help in a specific library problem, such as school library quarters, book selection or book processing, and (2) a visit for the purpose of accrediting the school, either by the university or by the North Central Association of Secondary Schools and Colleges. A total of 94 visits were made by the school library consultant last year, 55 by the consultant alone, 35 with university accrediting teams and four with North Central Association visitors.

Education and library conferences offer another means for the consultant to reach large groups of interested people with suggestions for improved school li- brary service. Eighteen such conferences were attended last year. Public and county librarians have cooperated with the consultant in these area conferences. The school library consultants of the Michigan State Library also work closely with this department in area conferences and workshops, and by an exchange of reports and reading lists.

2. Book List Service. For many years the service has compiled book lists on educational topics for distribution to graduates and former students of the university. The university faculty cooperates in the compilation of lists on technical topics. These alumni lists, together with special lists of library and teaching aids, compiled to help teachers, school librarians and administrators, and for distribution to those registered at conferences, offer a real service to individuals. Titles of current bibliographies of general interest have been listed in university publications and are available to anyone on request. During the last year some 2,800 reading lists were distributed to residents of Michigan and alumni of the university in California, Florida, Illinois, Louisiana, Maryland, Massachusetts, Nebraska, New Jersey, New York, Ohio, Pennsylvania, Tennessee, Virginia and Washington.

The department cooperates with the University Broadcasting Service in compiling reading lists of supplementary materials for teachers' manuals for the Michigan Radio Classroom Series.

3. Exhibits. Each year the service is asked to arrange exhibits of educational materials on topics covered by conferences sponsored by units of the university. The exhibits consist of pamphlet materials from the service files, supplemented by books from the university library. The majority of exhibits are held in Ann Arbor, but off-campus exhibits can be arranged if the conferences have some educational connection.

Exhibits for the Parent-Education Institute, Pastor's Conference, Adult Edu- 
cation Institute, Conference on Aging, Summer Education Conference and Citizenship Conferences are arranged yearly. Special exhibits of children's books and exhibits of material on Michigan, citizenship, and on school libraries are sent on request or are arranged by a staff member involved in an off-campus activity.

These exhibits give the library extension staff members an opportunity to exchange ideas with the registrants and to learn of their educational needs. To the conferees the wealth of material available in inexpensive form is a revelation. Patrons of these exhibits are invited to borrow packages of materials to supplement their local library facilities.

4. Workshops. Each year the summer session of the university offers workshops both off-campus and on-campus that are open for non-credit election. The Library Extension Service arranges working collections of supplementary materials for the use of the people enrolled in these short programs. During the regular sessions a collection of books is available to lend to cooperating local libraries to support university off-campus classes.

5. Off-Campus Services of Other Departments of the University Library. Other departments of the university library give off-campus service. The Interlibrary Loan Section of the Reference Department, in addition to lending materials for the students and faculty of all colleges in the state, has a very large clientele among public libraries, industrial concerns, research laboratories, government agencies, hospitals and sanitaria all over the country. Some $11 \%$ of the interlibrary loan activity is conducted with the librarians of these agencies needing old as well as current technical material. Many Michigan industries are numbered among the regular borrowers and the service constitutes another real contribution the university library makes to the welfare of the state and the nation.

The reference librarian reports the following information concerning last year's interlibrary loan service: a total of 3,870 books were lent, including Engineering Research Institute Reports and 674 medical books. Of these, 1,131 books were lent to 100 Michigan institutions. The department prepared for photostat or microfilm an additional 1,341 items, in lieu of lending. Research is often necessary to locate the material wanted by the borrower and record keeping and correspondence are a necessary part of the service. Sixty-eight industrial firms, 20 research institutes, 25 hospitals and sanitaria borrow material regularly from the university library through the Interlibrary Loan Section.

In addition, correspondence from individuals requests information of an elusive nature that requires long search and detailed replies. The reference librarian estimates the receipt of about 40 of these letters a week, a majority of them from Michigan residents.

The Engineering Library is a depository for Atomic Energy Commission research and development reports. A large proportion of all non-classified reports issued by the commission and its contractors is available there. A complete file of the index to the publications, the Nuclear Science Abstracts, and ready access to AEC reports through the commission's Technical Information Service makes procedures, data and results available to scientists, engineers and technologists. The Atomic Energy Commission recently recognized general industry's interest in these reports by allowing their widespread use and duplication.

The Photoduplication Department made some 15,800 photostats and 402 microfilms last year. The latter varied in length from three exposures to 26,496. While some of these were made for other educational institutions in line with usu- 
al cooperative practice, the Photoduplication Department estimates that $75 \%$ was for industrial research and governmental agencies in Michigan and elsewhere.

In addition, research workers in Ann Arbor and elsewhere use the open shelves of the many divisional libraries and the books in the reference room, stacks, and rare book room for study here in Ann Arbor. Divisional librarians report that visitors who come to campus for conferences use their special collections for individual research both at that time and on other occasions. The special collections in the Michigan Historical Collections, the Clements Library, the Legal Research Library, and the Business Administration Library are all open to the public for advanced research.

\section{MeAsurement}

In some 38 years of service to the state, about 70,000 requests for help have been received in the Library Extension Service and over a million pieces of information have been searched, packaged and sent to residents. The only cost to the borrower is the postage to return the package to Ann Arbor. It is difficult to measure the effect of a service that operates principally by mail and asks no report from borrowers, but repeated requests from the same sources testify to satisfactory service and continuing needs.

Last year a high school in the Upper Peninsula requested material on 96 different subjects for senior term papers: this year the same instructor wrote again. Some clubs in areas not served by local libraries depend upon the service year after year, not only for help in planning whole club programs, but for material for individual reports. Some rural schools in less favored areas turn to the children's book service as the only means of introducing students to current books for recreational reading. Many schools, eager to expand their library service to all their students, request help from the consultant in improving their library resources. Many librarians and teachers in elementary schools, as well as parents, use the booklists year after year as buying guides for their book purchases. The play-lending service is a real boon to the bewildered teacher assigned the task of selecting and directing the school play. The annual debate bibliography gives practical help to the debate coach and his team in some schools, and in other schools, to whole classes formed into discussion groups.

It is a source of real pride to the service that each letter or request is answered promptly, either through the university library's resources, through some other university unit, or by referral to another suitable source of information. The service sent help of some kind to 82 of the 83 counties in Michigan last year. University students in 32 communities had the benefit of access to over 3,000 books to add to their professional background or their understanding of the world around them. The package service, sent to every corner of the state, brought help on current problems and the book exhibits brought current publications to communities with limited local library facilities. The activities of the school library consultant served as a two-way street bringing to the service the problems and needs of schools and libraries all over the state; to the schools, the practical assistance and advice so earnestly sought. The generosity of the university faculty in helping with reading lists brought to many Michigan residents the advantages of long experience and technical background. All aspects of the department's activities were enriched by access to university library tools and book stock.

Through its many types of activities the Library Extension Service is reaching Michigan residents of all ages: young children through the book service; the high school age through the package service; the adult group through confer- 
ences, club program planning, book lists, and work with the Michigan Congress of Parents and Teachers, the Michigan Federation of Women's Clubs, the Michigan Council for UNESCO, and the Michigan Adult Education Association. The department staff takes an active interest in professional library matters through membership in the American Library Association, and work with the Michigan Library Association, the Michigan Association of School Librarians and local library clubs.

The Michigan State Library is the other large unit organized to give statewide service to Michigan residents. This service takes several forms: reference service to state officials and government agencies; administration of state aid grants to public libraries with accompanying responsibility for checking on standards of personnel and service; demonstration library and bookmobile services; a materials lending service; and a consulting service.

The State Library through its governing board, the State Board for Libraries, is responsible for the development, extension, improvement and coordination of library services throughout the state. It places special emphasis on the promotion and advancement of public libraries, while the University Library Extension Service places its major emphasis on help to elementary, secondary and university students. Both the State Library and the Library Extension Service carry on their material lending services through existing library units, only offering to help individuals beyond the service areas of organized libraries.

It is estimated by the State Board for Libraries that 830,000 people in Michigan are without library service. There are some 5,300 public, parochial, and private elementary and high schools in Michigan struggling to enrich their programs. The work of both the Michigan State Library and the University's Library Extension Service must be extend- ed if adequate library service to fill the needs of Michigan residents for educational materials is to be provided.

\section{Future Demands}

\section{Continuing Demands}

Most libraries, especially the smaller school and public ones, are hampered by lack of staff and access to sources from finding out about the wide variety of inexpensive current publications that present varying viewpoints and supplement books. It seems likely that even if all people in the state had access to local libraries, there would still be an opportunity for the Library Extension Service to supplement advantageously the local facilities with special types of material.

Teachers trained by modern methods rely on a variety of materials other than the textbook. The service can continue to be a source of supplementary material for all school libraries except those in metropolitan areas. For small schools unable to employ a full-time, trained librarian the service will be the main source of material for special projects and extra-curricular activities for the students and a source of information on professional matters for the instructional staff.

\section{Future Needs of Elementary Schools}

During the next few years while local school boards are struggling to provide classrooms for increasing numbers of children enrolled in grammer school, it will be most difficult to provide adequate book service. There will be continued and expanding need for the children's book-lending service as long as the present educational crisis exists. It is estimated that 275,000 children in Michigan now have no access to public libraries and most of these youngsters go to schools without elementary libraries. This number will not decrease as long as the birth rate stays at its present high level. 
The Library Extension Service is limiting its offerings to elementary schools to short term loans of children's books. This has come about mainly because of lack of staff and budget to reach them. With more staff the service could undertake to send out regular mailings calling the attention of the elementary teaching staff to current ideas in curriculum planning, teaching aids, school-community relations and student activities, and offering the package service as is now done for high schools.

School administrators should be encouraged to plan for provision of good library service for the elementary grades, as well as for the high school. The University Library Extension Service, cooperating with the University's Bureau of School Services, can assist in this. Parent-Teacher Associations and other volunteer groups have requested practical assistance, through workshops and area conferences, in the mechanics of furnishing minimum library services. More such workshops and conferences could be arranged for the benefit of these groups as well as teacher-librarians.

\section{Future Needs of Michigan High Schools}

In a recent survey conducted by the Bureau of School Services, the accrediting activities of the university were judged valuable by school administrators. As more schools seek this stamp of approval, which includes a check of library facilities, additional consultants will need to be added to the staff. Here again the present program of workshops and area conferences might be expanded to reach larger groups of school people. The consultant service of the State Library and the staffs of country libraries have cooperated in the past in these activities and can be relied upon to continue that support.

In the past the Library Extension Service has had the staff to handle only one mailing per year to Michigan high schools, inviting them to borrow the ma- terials in the department files. Many excellent, inexpensive teaching aids are received in the department regularly. More staff would allow duplication of lists of such materials to be distributed regularly to high school administrators and through them to the teaching staff. This would serve two purposes: it would call the attention of the teaching staff to new materials difficult to find without access to a wide range of selection aids and it would remind the school that the university has off-campus services to assist them.

The book lending of the Library Extension Service is presently limited to books to support university extension classes and to supplementary recreational reading for the elementary grades. While many high schools accredited by the university and the North Central Association of Secondary Schools and Colleges have school libraries, there will be a need for a supplementary service while schools are in the process of meeting standards. On the advice of the Bureau of School Services' consultants, the Library Extension Service could undertake to supplement the local high school collection with recreational reading on the secondary level in much the same manner as is done now in the elementary field. This would be a new field of operations and can only be undertaken with added staff and funds.

The Library Extension Service hears about the needs of these accredited schools through school visiting reports. Not so often heard of, but certainly no less acute, is the need of the non-accredited school. The needs of the students in these schools for up-to-date materials, not only to supplement the curriculum but also to fill social and recreational needs, are every bit as pressing as that of the student in the larger school. The Library Extension Service would like to be in a position to offer a recreational book-lending service as well as pamphlet service to this group of high schools. 
There is a real need in the state for a place to which high school and elementary school faculty committees might be referred for up-to-date courses of study and curriculum outlines. These materials are sometimes available only to teacher-training institutions and often are rather expensive. Schools wanting to consult large numbers of them would appreciate having a source to which they could turn to borrow typical examples from outstanding school systems. The Library Extension Service would welcome added funds to undertake the offcampus aspect of a service that is offered to on-campus students through the curriculum materials laboratories of the School of Education libraries.

\section{Future Needs of University Off-Campus Students}

The responsibility of the University in advancing the education of adults all over the state has been demonstrated by the expanding extension offerings and the creation of a number of residence centers. Library service to these off-campus students is expanding steadily, requiring a larger book stock and increased staff time to handle requests. Local libraries throughout the state cooperate willingly in this service and some undertake to add to the materials available from Ann Arbor. It will be difficult, however, for any but the very large public libraries to furnish the technical and special interest materials needed for some of these classes. Expanded staff and added book funds therefore will need to be provided as extension centers are added and class offerings are increased.

One of the pressing needs of students registered in off-campus classes is for access to professional journals in education, sociology, psychology and social work. This is especially important for graduate students engaged in advanced work. Added book funds would allow this type of material to be made available in the extension centers.

The university's interest in its graduates and former students is continuous. The department can furnish practical help to alumni groups by developing study outlines on current topics of general interest. A good example of this is a recent program of study on the revision of the United Nations Charter, in which many adult groups are especially interested this year. This service will be an expansion of the help presently offered individual alumni through reading lists on technical topics.

The Television Studio and the Broadcasting Service report a real need for a unit on the campus to which they may refer viewers and listeners for supplementary materials. Both studios would welcome book lists which could be announced and which would help to make any program a more complete educational experience. Both units indicate an interest in bibliographies of books that might be used in the local area where the program is aired for displays to carry on the theme set by the program. A Paul Bunyan program produced by the Broadcasting Service is one type of program that the Library Extension Service could support with booklists and information about displays. Future plans include a series on people of international fame.

In none of these services would the intent be to act as a substitute for adequate local library service or to substitute for cooperative programs of schools and local libraries. The need for more books and non-book materials and for more services to extend the use of books, is evident everywhere and far beyond the ability of any one agency to satisfy. 